\title{
ИННОВАЦИОННЫЙ МОЛОЧНО-РАСТИТЕЛЬНЫЙ ДЕСЕРТ
}

\section{INNOVATIVE DAIRY-VEGETABLE DESSERT}

\author{
Пилипенко Д.Н., кандидат сельскохозяйственных наук \\ Божкква C.E., кандидат биологических наук \\ Pilipenko D.N., candidate of agricultural sciences \\ Bozhkova S.E., candidate of biological sciences \\ Поволжский научно-исследовательский институт \\ производства и переработки мясомолочной продукции, Волгоград
}

Volga region research institute of manufacture and processing of meat-and-milk production, Volgograd

В статье рассматривается вопрос производства инновационного молочно-растительного десерта сметанного типа, предназначенного для специального питания, обогащенного ненасыщенными жирными кислотами, фруктозой, комплексом витаминов и минеральных элементов, что повысит биологическую ценность продукта. Использование в рецепте тыквенного масла первого холодного отжима, содержащего большее количество витамина Е, защищает клетки от «атаки» свободных радикалов, улучшает работу мозга и мышц. Для улучшения органолептических свойств продукта предлагается использовать овощной сироп на основе фруктозы - заменителя сахара с широким спектром положительных свойств, наиболее важными из которых являются высокая степень сладости и хорошая растворимость. Конечный продукт - молочно-растительный десерт сметанного типа, может использоваться для специального питания и особенно рекомендован лицам со склонностью к заболеваниям эндокринной системы.

The article is studied the production of innovative milk-and-vegetable dessert of sour cream type, intended for special nutrition enriched with unsaturated fatty acids, fructose, a complex of vitamins and mineral elements, which will increase the biological value of the product. Using in the recipe first cold pressed pumpkin seed oil, which contains more vitamin E, protects cells from "attacking" free radicals, improves the work of the brain and muscles. To improve the organoleptic properties of product, it is proposed to use vegetable syrup based on fructose - a sugar substitute with a wide range of positive properties. The most important of vegetable syrup is a high degree of sweetness and good solubility. The final product is milk-and-vegetable dessert of sour cream type, it can be used for special nutrition and is especially recommended for people with a tendency to endocrine system diseases.

Ключевые слова: молочная промышленность, функциональные продукты питания.

Keywords: dairy industry, functional food products.

Работа выполнена в рамках государственного задания ГНУ НИИММП по теме АААА-А17117033110080-5.

В последние 15 лет работниками здравоохранения зафиксирован значительный рост заболеваний эндокринной системы человека. Одним из самых распространенных таких заболеваний является сахарный диабет, что связано с неправильным питанием населения, урбанизацией и увеличенной стрессовой нагрузкой. Провоцирующими факторами в развитии болезни нередко бывают питание, особенно злоупотребление сахаром и иными рафинированными углеводами, стрессовые состояния, др. Кроме того, появилось много случаев так называемого «скрытого диабета», когда болезнь до поры до времени ничем себя не проявляет и протекает скрытно [1].

Поэтому в настоящее время рекомендуется соблюдение в первую очередь профилактического питания. В рацион не рекомендуется включать такие продукты, как сахар, глюкоза, мука высшего сорта, и продукты, их содержащие. Особое место в диетическом питании отводится комбинированным молочным продуктам [2].

Сметана в рационе питания так же необходима, как и другие молочные продукты. В ней содержится группа особо востребованных организмом витаминов ( $A, C, E, B, D, H$ и др.), необходимых любому чело- 
веку, микро- и макроэлементы (цинк, кальций, калий, кремний, др.). Для профилактики сахарного диабета и ожирения лучше подойдет десертный продукт на основе сметаны с низкой жирностью (10-15\%).

Для расширения ассортимента диетических продуктов предлагается разработанный комбинированный сметанный продукт - десерт с комплексом витаминов и минеральных элементов.

В качестве источника функциональных компонентов рецептура сметанного продукта включает масло тыквенное «Волгоградское» в количестве 3\% [3]. Натуральное масло из семян тыквы, полученное методом первого холодного отжима в комплексной аналитической лаборатории ГНУ НИИММП, содержит большее количество витамина Е, которое защищает клетки от «атаки» свободных радикалов, улучшает работу мозга и мышц. Для придания десерту однородной плотной консистенции целесообразно использовать пищевой агар - самый сильный желирующий агент.

Для повышения пищевой и функциональной ценности продукты питания рекомендуется обогащать комплексом биологически активных веществ, за счет которых компенсируется потребность организма в эссенциальных компонентах $[4,5,6,7]$.

Для улучшения органолептических свойств продукта предлагается использовать фруктозу и овощной сироп на её основе. Фруктоза - современный заменитель сахара с широким спектром положительных свойств. Наиболее важными являются высокая степень сладости, хорошая растворимость. Больным диабетом и людям, страдающим ожирением, фруктоза рекомендована в первую очередь.

Технология нового комбинированного продукта состоит из следующих операций: нормализация сливок, гомогенизация и пастеризация их, охлаждение до температуры заквашивания, сквашивание, охлаждение и созревание. В настоящее время сметану изготавливают преимущественно резервуарным способом. Вследствие неизбежных механических воздействий на сгусток сметанного десерта при смешивании с фруктозой и агаром, и последующей операции фасования происходит заметное разрушение его структуры, что разжижает продукт, изменяет его структурно-вязкостные показатели. В производстве сметанного десерта сливки рекомендуется пастеризовать после гомогенизации, так как существует вероятность повторного обсеменения сливок в процессе гомогенизации. Основные стадии производства продукта представлены на рисунке 1.

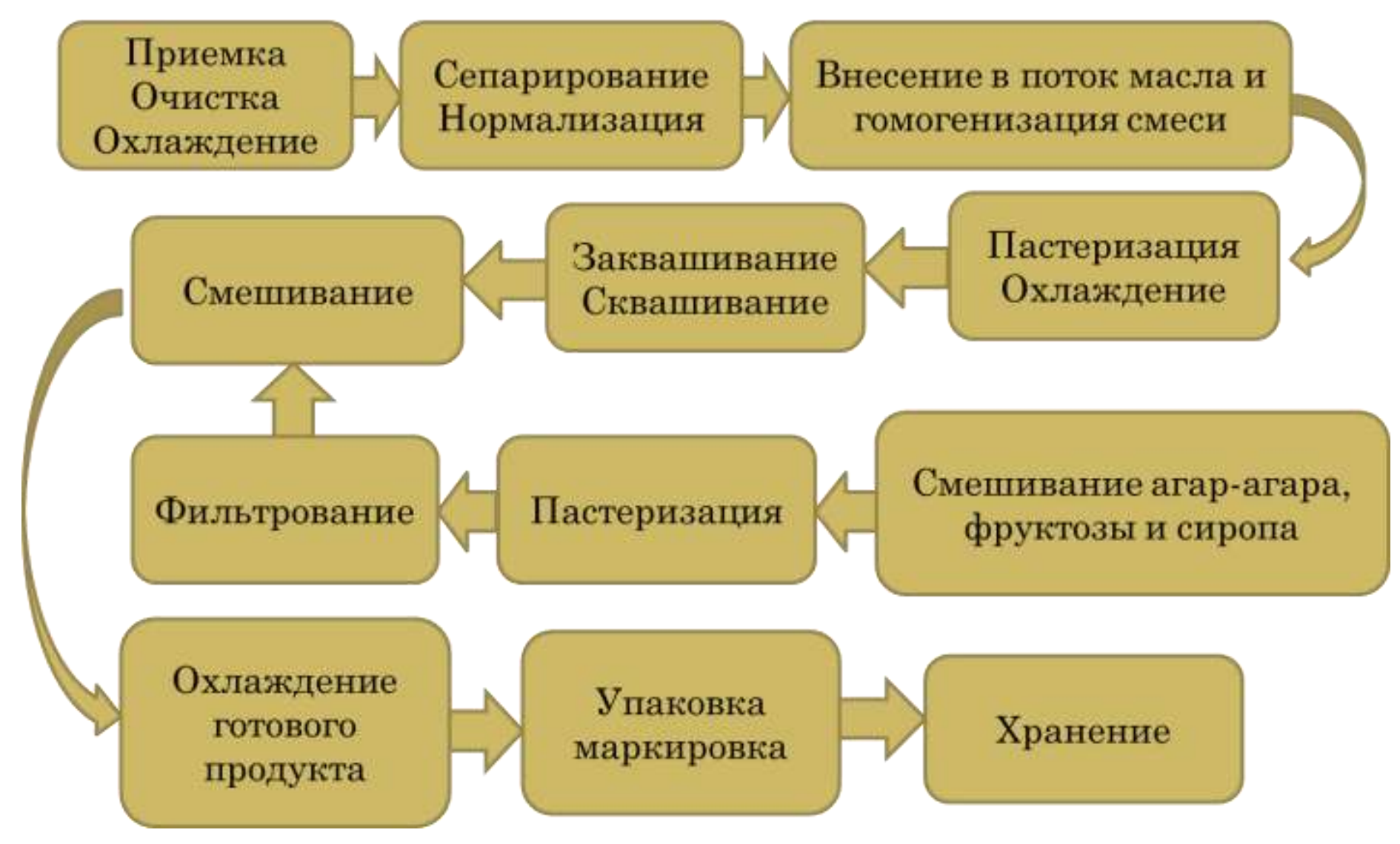

Рисунок 1 - Основные стадии производства продукта

В ходе экспериментальной части работы были произведены два образца (№ 1 и № 2) комбинированного сметанного десерта и проведена их органолептическая оценка, результаты которой отражены в таблице 1. Для обогащения вкуса при производстве образца № 2 использовался натуральный сироп «Тыквенный» на фруктозе («Bio National», Россия) в количестве 3\%. 
Таблица 1 - Органолептические показатели экспериментальных образцов

\begin{tabular}{|c|c|c|}
\hline \multirow{2}{*}{ Показатель } & \multicolumn{2}{|c|}{ Характеристика } \\
\hline & Образец № 1 & Образец № 2 \\
\hline Вкус и запах & молочный, чистый & $\begin{array}{c}\text { молочный, с приятным } \\
\text { тыквенным ароматом }\end{array}$ \\
\hline Внешний вид & $\begin{array}{c}\text { однородная консистенция, } \\
\text { без сыворотки }\end{array}$ & $\begin{array}{c}\text { однородная консистенция, } \\
\text { без сыворотки }\end{array}$ \\
\hline Цвет & однородный, белый & однородный, светло-бежевый \\
\hline Вкус и запах & $\begin{array}{c}\text { сметанный, сладковатый, } \\
\text { свежий }\end{array}$ & $\begin{array}{c}\text { сметанный, с тыквенным } \\
\text { привкусом }\end{array}$ \\
\hline
\end{tabular}

Органолептические показатели полученных продуктов полностью отвечали поставленной задаче - в десерте не ощущались посторонние нежелательные вкус и запах.

В таблице 2 приведены основные физико-химические показатели нового комбинированного сметанного продукта (образец № 2) в сравнении с контрольным образцом - сметаной $10 \%$ жирности.

Таблица 2 - Основные физико-химические показатели продуктов

\begin{tabular}{|c|c|c|}
\hline \multirow{2}{*}{ Показатель } & \multicolumn{2}{|c|}{ Характеристика } \\
\cline { 2 - 3 } & $\begin{array}{c}\text { Сметана 10\% } \\
\text { жирности }\end{array}$ & $\begin{array}{c}\text { Сметанный продукт с заменителем } \\
\text { молочного жира }\end{array}$ \\
\hline Содержание жиров, \% & 10,0 & 10,0 \\
\hline белков, \% & 2,7 & 3,7 \\
\hline углеводов, \% & 3,9 & 119 \\
\hline Калорийность, ккал & 119 & 80 \\
\hline Кислотность, ${ }^{\circ} \mathrm{T}$ & 90 & 10 суток \\
\hline Срок годности & 10 суток & \\
\hline
\end{tabular}

Физико-химические показатели экспериментальных продуктов соответствовали требованиям, предъявляемым потребителями к продуктам сметанного типа.

Тыквенное масло обладает выгодным сочетанием ненасыщенных жирных кислот. Это позволяет ему приводить жировой баланс в организме в норму, придавать эластичность сосудам, снижать в крови уровень «вредного» холестерина. Масло используют для лечения почечнокаменной болезни, болезней желчевыводящих путей и печени, ожирения и сахарного диабета.

Таким образом, применение тыквенного масла позволяет обогатить продукт комплексом витаминов, микро- и макроэлементами, тем самым повышая биологическую ценность продукта. Использование в рецептуре фруктозы и овощного сиропа на её основе позволяет рекомендовать сметанный продукт для профилактического питания, в том числе для питания больных сахарным диабетом.

\section{Библиографический список}

1. Балаболкин, М.И. Диагностика и классификация сахарного диабета. / М.И. Балаболкин, Е.М. Клебанова, В.М. Креминская // Сахарный диабет. - 1999. - № 3. - С. 11-18.

2. Лапшинская, Н.А. Молочные продукты с комбинированной жировой фазой. / Н.А. Лапшинская, Н.А. Драгун, Ю.Ю. Аленичева // Сибирский торгово-экономический журнал. - 2009. - № 8. - С. 163-165.

3. ТУ 9141-121-10514645-06 Масло тыквенное «Волгоградское». - Введ. 01.09.2012. - Волгоград: Поволжский научно-исследовательский институт производства и переработки мясомолочной продукции, 2012. - $18 \mathrm{c.}$

4. Горлов, И.Ф. Биологически активная добавка к пище / И.Ф. Горлов, С.Е. Божкова, Е.С. Юрина, А.А. Мосолов, М.И. Сложенкина, Н.А. Лупачева // Официальный бюллетень «Изобретения. Полезные модели», RU 2370151. - 2009. - № 29.

5. Горлов, И.Ф. Биологически активная добавка к пище / И.Ф. Горлов, А.А. Мосолов, С.Е. Божкова, Е.С. Юрина, Е.В. Абдрозякова, А.В. Балышев // Официальный бюллетень «Изобретения. Полезные модели», RU 2400107. - 2010. - № 27.

6. Божкова, С.Е. Использование функциональных компонентов для производства молочных продуктов специального назначения / С.Е. Божкова, Д.Н. Пилипенко, Е.Г. Духанина // Разработка инновационных технологий производства животноводческого сырья и продуктов питания на основе современных биотехнологических методов: мат. Междунар. науч.-практ. конф. - Волгоград, 2016. - C. 417-419. 
7. Пилипенко, Д.Н. Новые наполнители для кисломолочных продуктов / Д.Н. Пилипенко, С.Е. Божкова, Е.С. Юрина // Интеграционные процессы в науке, образовании и аграрном производстве залог успешного развития АПК: мат. Междунар. науч.-практ. конф. - Волгоград, 2011. - С. 369372. 